\title{
An Investigation of Heavy Metal Accumulation in Macrofungi Around the Seydisehir District
}

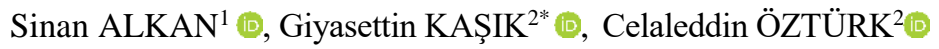 \\ ${ }^{1}$ Selcuk University, Çumra School of Applied Sciences, Organic Agriculture Administration Department, \\ Konya, TURKEY \\ ${ }^{2}$ Selçuk University, Science Faculty, Department of Biology, Konya, TURKEY \\ *Corresponding Author: giyasettinkasik@ hotmail.com
}

Received Date: 31.12 .2019

Accepted Date: 19.07.2020

Abstract

Aim of study: In this study, heavy metal accumulation, around aluminum plants in the Seydişehir district and in the areas close to them were investigated.

Area of study: Macrofungi samples were collected in the field studies carried out between 2015-2017 in the forest areas in Konya province Seydişehir district and its surrounding. In the study areas, twentytwo different species were identified in seven different localities.

Material and methods: Macrofungi grown in the area were identified and heavy metals were analyzed by the ICP-MS in the macrofungi.

Main results: According to the obtained data, the amounts of $\mathrm{Fe}$ and $\mathrm{Al}$ in Seydişehir soils were found to be excessive compared to the other heavy metals examined. According to the obtained data, the fungi species with the highest content of heavy metals detected was Pleurotus eryngii, (DC.) Quél. collected from Upper site of Toki, and the smallest content of heavy metals in total were found in Suillus collinitus (Fr.) Kuntze collected from the Madenli 2 locality, Gymnopus dryophilus (Bull.) Murrill collected from the Kuğulu Park locality, and Russula queletii collected from the Pond locality.

Research highlights: Caution should be exercised in the consumption of macrofungi grown in soil rich in heavy metals. Excessive consumption can have a negative effect on human health.

Keywords: Macrofungi, Heavy Metals, Pollution, Seydişehir, Konya, Turkey

\section{Seydişehir İlçesinin (Konya-Türkiye) Çevresindeki}

\section{Makromantarlarda Ağır Metal Birikimlerinin Araştırılması}

Öz

Çalışmanın amacı: Bu çalışmada Seydişehir ilçesinde bulunan Alüminyum tesislerin çevresinde ve ilçeye yakın alanlarda yetişen özellikle yenen makromantarlardaki ağır metal birikimleri araştırılmıştır.

Çalışma alanı: Konya İli Seydişehir İlçesi ve çevresindeki ormanlık alanlarda 2015-2017 yılları arasında yapılan arazi çalışmalarında makromantar örnekleri toplanmıştır. Arazi çalışmalarında 7 farklı lokaliteden 22 farklı tür tespit edilmiştir.

Materyal ve yöntem: Yörede yetişen makromantarlar tespit edilmiş ve elde edilenler makromantarlarda ICP-MS ile ağır metal analizleri yapılmıştır.

Temel sonuçlar: Elde edilen verilere göre Seydişehir topraklarında Fe ve Al miktarları incelenen diğer ağır metallere göre çok fazla miktarda bulunmuştur. Elde edilen verilere göre toplamda ağır metal içeriği en fazla olan mantar türü Toki Üzerinden toplanan Pleurotus eryngii, (DC.) Quél.'de, toplamda en az ağır metal içeriği ise Madenli 2 lokalitesinden toplanan Suillus collinitus (Fr.) Kuntze, Kuğulu Park lokalitesinden toplanan Gymnopus dryophilus (Bull.) Murrill ve Gölet lokalitesinden toplanan Russula queletii türlerinde tespit edilmiştir.

Araştırma vurguları: Ağır metaller açısından zengin topraklarda yetişen makromantarların besin olarak tüketilmesine dikkat edilmelidir. Aşırı tüketim insan sağlığı açısından sakıncalı durumlar oluşturabilir.

Anahtar kelimeler: Makrofunguslar, Ağır metal, Kirlilik, Seydişehir, Konya, Türkiye

\section{Introduction}

The vegetative structures of the macrofungi are generally made of cylindrical, tubular cells.
The fungi cell is composed of micelle and hyphae. Micelles come together and make up mycelium tissues. The main structure of the wall is chitin in macrofungi. In addition, 
different polysaccharides are involved in the cell structure (Campbell \& Reece, 2008; Kaşı, 2010). Depending on the main wall materials and the species and hyphae structure, lignin, callose, and some organic materials can be added (Campbell \& Reece, 2008).

Both of fungi groups that are harvested from nature and that are cultivated are important for nutrition and commercial uses. However, research during the past three decades on nutritive aspects of wild macrofungi has exposed their negative facet too (Lalotra et al., 2016). Macrofungi are classified as edible, inedible, and poisonous fungi when evaluated in terms of human nutrition. Since Turkey's fungi species is very wide variety, edible and poisonous mushroom species are frequently encountered in the same regions, and because local people do not distinguish the different types of fungi, there are reports every year in the media of dozens of cases mushroom poisoning. However, studies of macrofungi of Turkey are increasing rapidly. In this way, the spread of macrofungi and how many fungi types are available and while people's familiarity with mushrooms will be determined and also observed and revealed in Turkey. Heavy metals are elements that exhibit metallic properties such as ductility, malleability, conductivity, cation stability, and ligand specificity. They are characterized by relatively high density and high relative atomic weight with an atomic number greater than 20 (Raskin et al., 1994). Heavy metals are defined as minerals with a density of $5 \mathrm{~g} / \mathrm{cm}^{3}$. Heavy metals occupy an important place in terms of human health and environmental pollutants. It is known that these minerals in the soil are absorbed by plants and mushrooms and other living organisms.

The ability of plants to accumulate essential metals as the same of fungi equally allows of them to obtain other nonessential metals. Because metals cannot be broken down, when concentrations within the plant exceed optimal levels, they adversely affect the plant both directly and indirectly. Some of the straight toxic effects caused by high metal concentration include inhibition of cytoplasmic enzymes and damage to cell structures due to oxidative stress (Assche \& Clijsters, 1990). In addition, the increase in the rate of heavy metals in the soil has a negative effect on the growth and activities of soil microorganisms and can also indirectly affect the growth of plants, fungi, lichens and algae. For example, a decrease in the number of beneficial soil microorganisms due to high metal concentration can lead to a decrease in organic matter decomposition and a decrease in soil nutrients, causing direct or indirect damage to other living things.

The toxic effect of heavy metals on the environment is still among the biggest concerns of human life. Because the human son, who is with the big predators at the top of the food chain, takes the heavy metals accumulated in living tissues along this chain as food (Ihab et al., 2013). Also, for heavy metals absorbed into the body, there is a very narrow concentration range between beneficial and toxic effects, and when present above the threshold, it can pose a serious threat to human health. As a result, it can lead to morphological abnormalities, decreased growth and increased mortality (Olumuyiwa et al., 2007; Elekes et al., 2010; Radulescu et al., 2010; Lalotra et al., 2016).

The heavy metals eaten cause poisoning, cancer and brain damage (Al-Garni, 2005). It is very difficult to treat nutrients, soil, water and wastewater containing heavy metals. Purification methods for water and wastewater sedimentation, flotation, biosorption, electrolytic recovery, membrane separation, adsorption on minerals and activated carbon adsorption can be listed as methods (Esalah et al., 2000; Ho et al., 2001; Canet et al., 2002). However, most of these methods are expensive methods. Due to industrial and technological developments, heavy metals are constantly released into the environment, and contamination of agricultural land with heavy metals is an important problem in industry and defense related areas around the world (Amini et al., 2008). This problem is not only limited to the soil of agriculture but also affects forest areas and nature.

The concentration of heavy metals in the fruiting bodies of macrofungi is thought to depend on the type of fungus. But at the same time, other factors such as soil $\mathrm{pH}$, organic matter and clay content also play an important role in the accumulation and displacement of these heavy metals in fungi (Kalac \& Svoboda, 
2000; Gürsoy et al., 2009; Frankowska et al., 2010). In this study, heavy metal accumulations in the macrofungi of Seydişehir (Konya) district were examined. In this way, the situation in the fungus in terms of pollutants will be revealed.

Data on the absorption and accumulator properties of macrofungi are available in various publications, and there are also studies in different regions in Turkey (Tüzen et al., 1998; Sesli \& Tüzen, 1999; Demirbaş, 2000; Demirbaş, 2001a; Demirbaş, 2001b; Demirbaş, 2001c; Demirbaş, 2002; Yılmaz et al., 2003; Tüzen, 2003; Iş1ldak et al., 2004; Türkekul et al., 2004; Doğan et al., 2006; Yamaç et al., 2007; Gençcelep et al., 2009; Kaya \& Bağ, 2010; Uzun et al., 2011; Sarıkürkçü et al., 2012; Altıntığ et al., 2017; Akgül et al., 2016; Karapınar et al., 2017: Akın et al., 2019). Also, worldwide several researchers have investigated the heavy metal concentration in many wild growing fungi (Laaksovirta \& Alakuijala, 1978; Vetter, 1987; Lepsova \& Mejstrik, 1988; Lepsova \&
Kral, 1988; Kalač et al., 1989; Vetter, 1990; Thomas, 1992; Vetter, 1993; Vetter, 1994; Jorhem \& Sundström, 1995; Cibulka et al., 1996; Michelot et al., 1998; Svoboda et al., 2000; Kalač et al., 2004; Elekes et al., 2010; Magdziak et al., 2013; Mazurkiewicz \& Podlasinska, 2014; Wang et al., 2014; Dulay et al., 2015; Lalotra et al., 2016; Proskura et al., 2017). However, there is no study in the literature of the heavy metal content of the fungi in the study area.

In this study, it was aimed to investigate the heavy metal content of macrofungi in Seydişehir region and the effects of these heavy metals on soil.

Field studies in the town of Seydisehir were carried out between 2015 and 2017 in the autumn and spring months when the macrofungi were most active. In the preliminary study, the geographic structure of the research area and the suitable environments for fungi were determined (Figure 1).

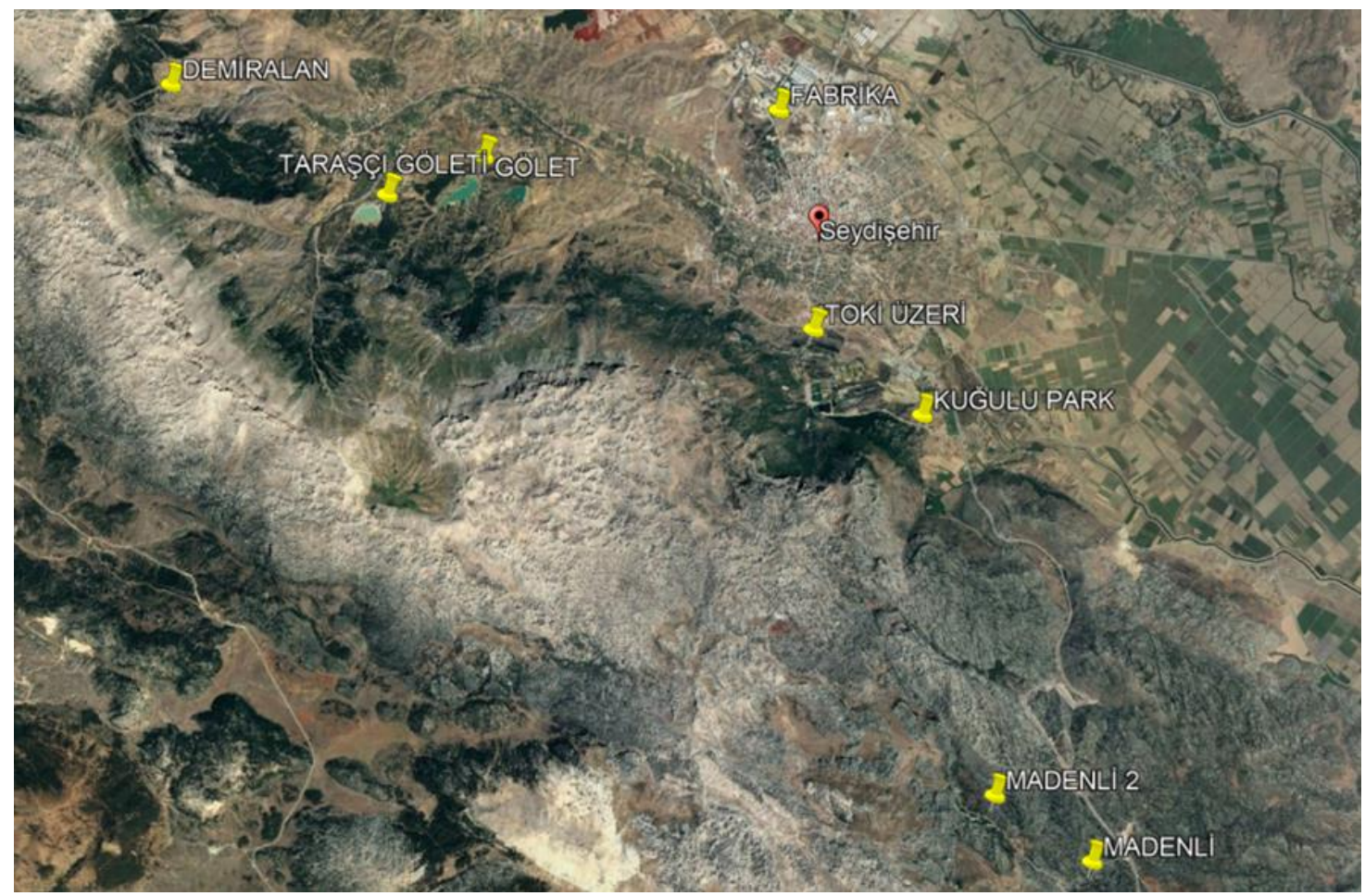

Figure 1. Research area

\section{Materials and Methods}

Photographs of the macrofungi detected in the field studies were taken, the samples were numbered, and their ecological and morphological characteristics were noted. Fungal samples were placed in aluminum foil, and the fungi was easily identified and 
examined in the laboratory. The soil samples were taken from the points where the mushroom samples were detected, they were placed in the polyethylene zipped bags, and a label number was placed in the bag. While taking soil samples, it was tried to be taken from a depth of approximately $20-25 \mathrm{~cm}$ by using anchors, knives and similar tools. Soil samples taken with sterile gloves were collected in locked nylon bags, 25-30 gr each. In addition, in order for the soil samples not to interfere with each other, a note with the locality, date, collection number, GPS coordinate and soil feature were written into the bags.

The macroscopic and microscopic features of the fungi were used as data in the diagnosis. While the dried samples were examined under the microscope (DM 1000 imaging system), their diagnosis was made with the help of appropriate literature (Phillips, 1981; Breitenbach \& Kränzlin, 1986; 1991; 1995; 2005; Grünert \& Grünert, 1984; 1991; Ellis \& Ellis, 1990; Dähncke, 1993; Smith \& Smith, 1996).

The fungi were first dried in the drying cabinet, and fungaryum samples were prepared from the samples that were dried. The fungi samples are stored in the fungarium at Selcuk University Fungal Research and Application
Center.

Dried and diagnosed mushrooms samples were washed with ultrapure water for heavy metal determination. It was dried at $45-50^{\circ} \mathrm{C}$ for one day and pulverized using blender. Soil samples, on the other hand, were cleaned of dry vegetal wastes and stone fragments, and made into fine powder using blender and the powdered samples were numbered. The samples were submitted to Selçuk University's ILTEK laboratory for analysis which was carried out in a ILTEK laboratory with ICP-MS. Both types of dried samples were weighed using an analytical balance of approximately 0.1 grams, four decimal places, and transferred to a screwcapped teflon incinerator. A mixture of $7 \mathrm{~mL}$ nitric acid and $3 \mathrm{~mL}$ hydrogenperoxide was added at room temperature. The containers were then burned in the microwave oven for 1 hour. The analysis of samples were performed using an Inductively Coupled Plasma Mass Spectrometry (ICP-MS).

\section{Results}

Macrofungi List

Table 1 shows the distribution of the mushroom species determined for analysis in the localities as a result of the field and laboratory studies.

Table 1. Macrofungi list and localities

\begin{tabular}{|c|c|c|c|}
\hline Localitie & Coordinate & Altitude & Examples/Edibility \\
\hline 1-Madenli & $\begin{array}{l}37^{\circ} 18^{\prime} 31 \mathrm{~K}, \\
031^{\circ} 52^{\prime} 44 \mathrm{D}\end{array}$ & $1450 \mathrm{~m}$ & $\begin{array}{l}\text { M1-Volvopluteus gloiocephalus /Edible } \\
\text { M2-Agaricus bisporus /Edible } \\
\text { M3-Inocybe erubescens /Poisonous }\end{array}$ \\
\hline 2-Madenli 2 & $\begin{array}{l}37^{\circ} 19^{\prime} 18 \mathrm{~K}, \\
031^{\circ} 51^{\prime} 43 \mathrm{D}\end{array}$ & $1597 \mathrm{~m}$ & $\begin{array}{l}\text { M1-Lycoperdon molle /Edible } \\
\text { M2-Suillus collinitus /Edible } \\
\text { M3-Agaricus bitorquis /Edible }\end{array}$ \\
\hline 3-Kuğulu Park & $\begin{array}{l}37^{\circ} 23^{\prime} 01 \mathrm{~K}, \\
031^{\circ} 51^{\prime} 38 \mathrm{D}\end{array}$ & $1138 \mathrm{~m}$ & $\begin{array}{l}\text { M1-Lycoperdon mammiforme /Edible } \\
\text { M2-Gymnopus dryophilus /Edible } \\
\text { M3-Cortinarius venetus /Poisonous } \\
\text { M4-Agaricus bisporus /Edible }\end{array}$ \\
\hline $\begin{array}{l}\text { 4- Upper site of } \\
\text { Toki }\end{array}$ & $\begin{array}{l}37^{\circ} 24^{\prime} 00 \mathrm{~K}, \\
031^{\circ} 50^{\prime} 45 \mathrm{D}\end{array}$ & $1125 \mathrm{~m}$ & $\begin{array}{l}\text { M1-Neoboletus erythropus /Edible } \\
\text { M2-Russula delica /Edible } \\
\text { M3- Pleurotus eryngii /Edible }\end{array}$ \\
\hline 5-Pond & $\begin{array}{l}37^{\circ} 26^{\prime} 14 \mathrm{~K}, \\
031^{\circ} 46^{\prime} 56 \mathrm{D}\end{array}$ & $1181 \mathrm{~m}$ & $\begin{array}{l}\text { M1-Boletus reticulatus /Edible } \\
\text { M2-Russula queletii /Poisonous } \\
\text { M3-Tricholomopsis rutilans /Non-Edible } \\
\text { M4-Amanita excelsa /Non-Edible } \\
\text { M5-Cantharellus cibarius /Edible }\end{array}$ \\
\hline $\begin{array}{l}\text { 6- The Taraşçı } \\
\text { Pond }\end{array}$ & $\begin{array}{l}37^{\circ} 25^{\prime} 58 \mathrm{~K}, \\
031^{\circ} 45^{\prime} 43 \mathrm{D}\end{array}$ & $1239 \mathrm{~m}$ & $\begin{array}{l}\text { M1-Clitocybe costata /Non-Edible } \\
\text { M2-Clitocybe foetens /Non-Edible } \\
\text { M3-Chroogomphus rutilus /Edible }\end{array}$ \\
\hline
\end{tabular}


(Table 1. Continued)

\begin{tabular}{|c|c|c|c|}
\hline 7-Demiralan & $\begin{array}{l}37^{\circ} 27^{\prime} 21 \mathrm{~K}, \\
031^{\circ} 43^{\prime} 21 \mathrm{D}\end{array}$ & $1583 \mathrm{~m}$ & $\begin{array}{l}\text { M1-Chroogomphus rutilus /Edible } \\
\text { M2-Suillus grevillei /Edible } \\
\text { M3-Hebeloma sinapizans /Poisonous }\end{array}$ \\
\hline 8- Factory & $\begin{array}{l}37^{\circ} 25^{\prime} 18 \mathrm{~K}, \\
031^{\circ} 50^{\prime} 55 \mathrm{D}\end{array}$ & $1186 \mathrm{~m}$ & \\
\hline
\end{tabular}

Analysis Results

As a result of the study, the heavy metal content was obtained from the mushroom samples and the soil samples. When the determined mineral content from the Madenli locality was examined (Table 2), it was found that the highest aluminum and the lowest lead was in M1, the highest aluminum and the lowest cobalt was in the M2, and the highest aluminum and the lowest cobalt is in the M3. When the soil taken from Madenli locality was examined in terms of minerals, it was observed that it was rich in aluminum and iron. Then, zinc, magnesium, chromium, and nickel density were also observed. In the fungi samples, copper and cadmium ratios were found to be higher in the soil and in terms of chromium, cobalt, nickel, lead, iron and aluminum, the soil ratios were higher. In terms of zinc and magnesium, the mineral density in the soil and mushroom samples was relatively equal.

Table 2. Heavy metal contents in fungi samples detected at the Madenli locality (ppm)

\begin{tabular}{cllll}
\hline & \multicolumn{1}{c}{$\begin{array}{c}\text { T1- } \\
\text { Madenli }\end{array}$} & \multicolumn{1}{c}{ M1-V. volvacea } & \multicolumn{1}{c}{$\begin{array}{c}\text { M2- } \\
\text { A.sporus }\end{array}$} & $\begin{array}{c}\text { M3- } \\
\text { I. erubescens }\end{array}$ \\
\hline $\mathrm{Cr}$ & 83217.722 & 10576.94 & 1983.422 & 6041.463 \\
\hline $\mathrm{Fe}$ & $\mathbf{3 7 1 8 4 0 3 0 . 2 4}$ & 954126.176 & 494813.211 & 2007690.72 \\
\hline $\mathrm{Co}$ & 25956.669 & 740.784 & $\underline{\mathbf{3 8 5 . 4 9 2}}$ & $\underline{\mathbf{1 2 7 5 . 4 1 9}}$ \\
\hline $\mathrm{Ni}$ & 82598.173 & 2756.448 & 1246.997 & 4814.196 \\
\hline $\mathrm{Cu}$ & 33654.812 & 155752.426 & 73094.695 & 71441.173 \\
\hline $\mathrm{Cd}$ & $\mathbf{4 5 2 2 . 1 9 3}$ & 16215.705 & 1095.791 & 12065.65 \\
\hline $\mathrm{Pb}$ & 34830.167 & $\underline{\mathbf{3 7 7 . 8 4 7}}$ & 684.299 & 4266.42 \\
\hline $\mathrm{Al}$ & 2750185.232 & $\mathbf{1 1 7 1 6 6 5 . 2 3 6}$ & $\mathbf{1 5 0 1 3 0 7 . 0 5 6}$ & $\mathbf{1 1 5 3 9 9 0 . 4 5 1}$ \\
\hline $\mathrm{Zn}$ & 127915.439 & 115113.59 & 115958.737 & 142951.951 \\
\hline $\mathrm{Mg}$ & 99090.018 & 77249.843 & 22829.401 & 98968.125 \\
\hline
\end{tabular}

When the mineral content of the fungi detected at Madenli locality 2 was examined (Table 3), in M1 aluminum was found to be at the highest amount and cadmium at the lowest; in M3, cobalt found to be at its lowest and aluminum at its highest. In addition, lead was not detected in the M2 and M3 samples. Al and Fe were the most common minerals in the soil samples of Madenli 2 locality. Following these, amounts of $\mathrm{Ni}, \mathrm{Cr}, \mathrm{Ni}, \mathrm{Zn}$ were also detected. More $\mathrm{Cu}$ and $\mathrm{Zn}$ were found in the fungi than in the soil. Although $\mathrm{Pb}$ was not detected in two of the fungi samples, it was found that one fungi sample contained more $\mathrm{Pb}$ than soil did.

Table 3. Heavy metal contents in fungi samples detected at Madenli 2 locality (ppm)

\begin{tabular}{cllll}
\hline & \multicolumn{1}{c}{ T2 } & \multicolumn{1}{c}{ Madenli 2} & \multicolumn{1}{c}{ M1-L. molle } & \multicolumn{1}{c}{$\begin{array}{c}\text { M2- collinitus } \\
\text { A. bitorquis }\end{array}$} \\
\hline $\mathrm{Cr}$ & 129426.436 & 8210.661 & 1041.095 & 2908.631 \\
\hline $\mathrm{Fe}$ & $\underline{\mathbf{2 7 4 7 3 2 1 3 . 6 3}}$ & 866241.054 & 173137.657 & 234111.147 \\
\hline $\mathrm{Co}$ & 26178.954 & $\underline{\mathbf{2 3 6 0 . 5 4 5}}$ & 506.477 & $\underline{\mathbf{4 4 5 . 7 0 7}}$ \\
\hline $\mathrm{Ni}$ & 329905.67 & 19040.726 & 761.257 & 3549.894 \\
\hline $\mathrm{Cu}$ & 32231.589 & 62976.332 & 7686.134 & 58649.853 \\
\hline $\mathrm{Cd}$ & $\mathbf{1 3 7 . 8 0 3}$ & 3924.711 & $\mathbf{3 8 . 6 9 1}$ & 869.39 \\
\hline $\mathrm{Pb}$ & 9149.192 & 39849.958 & $\underline{\mathbf{n o n e}}$ & $\mathbf{\text { none }}$ \\
\hline $\mathrm{Al}$ & 10165838.99 & $\underline{\mathbf{1 8 2 0 7 1 9 . 1 9 7}}$ & $\underline{\mathbf{8 2 7 9 7 7 . 5 1 7}}$ & $\underline{\mathbf{1 8 3 9 9 5 9 . 3 8 5}}$ \\
\hline $\mathrm{Zn}$ & 69938.837 & 131506.38 & 39995.646 & 88333.076 \\
\hline $\mathrm{Mg}$ & 127395.762 & $\mathbf{7 8 2 6 5 . 4 8 6}$ & 19821.611 & 51172.225 \\
\hline
\end{tabular}


In all of the fungi from the Kuğulu Park locality, aluminum was found to be at the highest level (Table 4). Lead was not detected in M2 and M3. Minerals found to be at their lowest amount in the fungi samples were lead in M1, Chromium in M2, Cobalt in M3 and M4. In the Kuğulu Park locality, the highest amount of $\mathrm{Fe}$ was observed in soil samples. Subsequently, the amounts of $\mathrm{Al}$, $\mathrm{Mg}, \mathrm{Zn}, \mathrm{Ni}$ were identified. More $\mathrm{Cu}, \mathrm{Zn}$ was found in fungi samples than in the soil. Although $\mathrm{Pb}$ was not detected in two of the fungi samples, it was found that two other fungi sample contained more $\mathrm{Pb}$ than soil did.

Table 4. Heavy metal contents in fungi samples detected at Kuğulupark locality (ppm)

\begin{tabular}{|c|c|c|c|c|c|}
\hline & $\begin{array}{c}\text { T3 } \\
\text { Kuğulu Park }\end{array}$ & $\begin{array}{c}\mathrm{M} 1-L . \\
\text { mammaeforme }\end{array}$ & $\begin{array}{c}\text { M2-G. } \\
\text { dryophilus }\end{array}$ & M3-C. venetus & $\begin{array}{c}\text { M4- } \\
\text { A. bisporus }\end{array}$ \\
\hline $\mathrm{Cr}$ & 29072.504 & 8210.661 & 1041.095 & 2908.631 & 8210.661 \\
\hline $\mathrm{Fe}$ & $\underline{25670226.940}$ & 866241.054 & 173137.657 & 234111.147 & 866241.054 \\
\hline Co & 11907.879 & 2360.545 & 506.477 & 445.707 & 2360.545 \\
\hline $\mathrm{Ni}$ & 42666.119 & 19040.726 & 761.257 & 3549.894 & 19040.726 \\
\hline $\mathrm{Cu}$ & 24027.744 & 62976.332 & 7686.134 & 58649.853 & 62976.332 \\
\hline $\mathrm{Cd}$ & 1045.973 & 3924.711 & 38.691 & 869.390 & 3924.711 \\
\hline $\mathrm{Pb}$ & 16032.553 & 39849.958 & none & none & 39849.958 \\
\hline $\mathrm{Al}$ & 1990880.346 & 1820719.197 & $\mathbf{8 2 7 9 7 7 . 5 1 7}$ & $\mathbf{1 8 3 9 9 5 9 . 3 8 5}$ & 1820719.197 \\
\hline $\mathrm{Zn}$ & 92884.818 & 131506.38 & 39995.646 & 88333.076 & 131506.380 \\
\hline $\mathrm{Mg}$ & 126033.101 & 78265.486 & 19821.611 & 51172.225 & 78265.486 \\
\hline
\end{tabular}

When the mineral content of the fungi determined from Upper site of Toki locality was examined (Table 5), the highest iron levels were found in all mushroom samples. The lowest levels were Cadmium in M1, cobalt in M2, and cadmium in M3. On the other hand, the highest amount of $\mathrm{Fe}$ was observed in the soil samples of the Upper site of Toki locality. The amounts of $\mathrm{Al}$ and $\mathrm{Zn}$ followed. The fungal samples contained more $\mathrm{Cu}, \mathrm{Zn}$, and $\mathrm{Mg}$ than the amounts detected in the soil.

Table 5. Heavy metal contents in fungi samples detected in Upper site of Toki locality (ppm)

\begin{tabular}{cllll}
\hline & \multicolumn{1}{c}{$\mathrm{T} 4$} & \multicolumn{1}{c}{$\begin{array}{c}\text { M1- } \\
\text { Upper site of Toki }\end{array}$} & $\begin{array}{c}\text { M. erythropus } \\
\text { P. delica }\end{array}$ & \multicolumn{1}{c}{$\begin{array}{c}\text { M3- } \\
\text { P. eryngii }\end{array}$} \\
\hline $\mathrm{Cr}$ & 28146.368 & 1472.399 & 2957.909 & 8910.256 \\
\hline $\mathrm{Fe}$ & $\underline{\mathbf{2 4 1 1 7 3 4 7 . 6 9}}$ & $\mathbf{9 0 9 8 3 8 . 4 9 4}$ & $\mathbf{1 3 6 5 2 7 4 . 5 1 4}$ & $\underline{\mathbf{5 6 3 7 6 0 2 . 9 5 0}}$ \\
\hline $\mathrm{Co}$ & 11556.847 & 490.445 & $\mathbf{6 2 7 . 0 6 3}$ & 2881.817 \\
\hline $\mathrm{Ni}$ & 42204.671 & 1480.944 & 2680.658 & 10397.806 \\
\hline $\mathrm{Cu}$ & 42365.505 & 13432.778 & 47318.883 & 117559.403 \\
\hline $\mathrm{Cd}$ & $\mathbf{1 4 1 2 . 0 0 6}$ & $\mathbf{1 5 1 . 9 1 3}$ & 12962.513 & $\mathbf{7 3 3 . 6 9 4}$ \\
\hline $\mathrm{Pb}$ & 17580.387 & 337.662 & 835.496 & 12925.527 \\
\hline $\mathrm{Al}$ & 1484868.413 & 622952.500 & 1053847.412 & 1370860.723 \\
\hline $\mathrm{Zn}$ & 88091.452 & 37093.049 & 52210.436 & 133798.535 \\
\hline $\mathrm{Mg}$ & 60607.686 & 847233.053 & 13462.605 & 327349.463 \\
\hline
\end{tabular}

The mushrooms detected from the pond locality were found to have the highest level of all except M5 (Table 6). Iron was found to be at its highest in M5. In M1, lead was at the lowest level, cobalt was lowest in M2, M3, and M4; and, in M5, the lowest was cadmium. No lead was detected in M2 and M3. At the pond locality, Fe was the mineral with the highest level in the soil samples followed by $\mathrm{Al}, \mathrm{Zn}, \mathrm{Mg}, \mathrm{Cr}$, and $\mathrm{Ni}$. The fungus samples contained more $\mathrm{Cu}, \mathrm{Zn}$, and $\mathrm{Mg}$ in than the soil.

In the fungi samples identified from the Taraşç locality, aluminum was found to be the highest in M1 and M3 and iron in M2 (Table 7). The lowest is found to be cobalt in M1 and M2, and lead was lowest in M3. At the Taraşç locality, the highest amount of $\mathrm{Fe}$ 
was observed in the soil samples followed by $\mathrm{Al}, \mathrm{Zn}, \mathrm{Cu}, \mathrm{Mg}$, and $\mathrm{Cr}$. More $\mathrm{Mg}$ was found in the fungi samples than in the soil.
Depending on the amount detected in the soil, more $\mathrm{Cu}$ and $\mathrm{Zn}$ was found in the fungi samples.

Table 6. Heavy metal contents in fungi samples detected at the pond locality (ppm)

\begin{tabular}{lllllll}
\hline & \multicolumn{1}{c}{$\begin{array}{c}\text { T5 } \\
\text { Pond }\end{array}$} & $\begin{array}{c}\text { M. reticulatus } \\
\text { R. queletii }\end{array}$ & \multicolumn{1}{c}{ T. rutilans } & \multicolumn{1}{c}{$\begin{array}{c}\text { M. excelsa } \\
\text { C. cibarius }\end{array}$} \\
\hline $\mathrm{Cr}$ & 31178.190 & 2853.495 & 2198.089 & 486.568 & 5792.021 & 10399 \\
\hline $\mathrm{Fe}$ & $\mathbf{1 9 5 8 2 4 1 1 . 3 1}$ & 455993.833 & 350412.425 & 115970.738 & 1017452.263 & $\mathbf{1 8 4 9 9 4 9 . 0 1 9}$ \\
\hline $\mathrm{Co}$ & 11289.413 & 370.753 & $\mathbf{2 7 6 . 8 5 8}$ & $\underline{\mathbf{1 3 9 . 4 6 9}}$ & $\mathbf{6 6 6 . 1 6 3}$ & 1036.299 \\
\hline $\mathrm{Ni}$ & 26954.817 & 2042.675 & 949.112 & 373.072 & 2405.33 & 3527.656 \\
\hline $\mathrm{Cu}$ & 27638.305 & 17514.321 & 25599.304 & 18638.373 & 56319.596 & 24679.859 \\
\hline $\mathrm{Cd}$ & $\mathbf{4 0 2 . 6 9 2}$ & 1338.907 & 543.685 & 3810.002 & 1819.101 & $\mathbf{3 9 0 . 5 2 4}$ \\
\hline $\mathrm{Pb}$ & 16343.625 & $\underline{\mathbf{1 3 8 . 3 3 7}}$ & $\underline{\mathbf{n o n e}}$ & $\underline{\mathbf{n o n e}}$ & 1969.168 & 1138.908 \\
\hline $\mathrm{Al}$ & 1880385.583 & $\mathbf{7 9 6 2 3 4 . 5 1 7}$ & $\mathbf{6 0 8 9 4 8 . 3 5 4}$ & $\mathbf{1 1 4 9 8 1 0 . 3 5}$ & $\mathbf{1 0 8 4 9 4 1 . 2 3 5}$ & 1019937.313 \\
\hline $\mathrm{Zn}$ & 62798.279 & $\mathbf{7 6 8 3 7 . 7 8 4}$ & $\mathbf{5 8 4 5 3 . 2 5 1}$ & 33508.774 & 130803.06 & 54495.367 \\
\hline $\mathrm{Mg}$ & 42022.419 & 15459.952 & 22701.091 & 104721.084 & 37878.347 & 11894.543 \\
\hline
\end{tabular}

Table 7. Heavy metal contents in fungi samples detected at The Taraşçı Pond locality (ppm)

\begin{tabular}{lllll}
\hline & \multicolumn{1}{c}{$\begin{array}{c}\text { T6 } \\
\text { The Taraş̧1 }\end{array}$} & \multicolumn{1}{c}{$\begin{array}{c}\text { M1- } \\
\text { C. costata }\end{array}$} & \multicolumn{1}{c}{$\begin{array}{c}\text { M2- } \\
\text { C. foetens }\end{array}$} & \multicolumn{1}{c}{$\begin{array}{c}\text { M3- } \\
\text { C. rutilus }\end{array}$} \\
\hline $\mathrm{Cr}$ & 28651.941 & 3197.869 & 2075.242 & 2576.917 \\
\hline $\mathrm{Fe}$ & $\underline{\mathbf{2 5 4 5 7 4 5 5 . 3 1 0}}$ & 1198878.27 & $\underline{\mathbf{1 0 4 0 4 2 7 . 9 1 9}}$ & 918864.936 \\
\hline $\mathrm{Co}$ & 13871.601 & $\underline{\mathbf{1 4 3 0 . 6 2 3}}$ & $\mathbf{6 0 2 . 6 4 7}$ & 495.883 \\
\hline $\mathrm{Ni}$ & 22880.592 & 3120.931 & 3167.340 & 2866.249 \\
\hline $\mathrm{Cu}$ & 75106.306 & 45779.473 & 13860.521 & 11008.770 \\
\hline $\mathrm{Cd}$ & $\mathbf{9 6 . 7 0 5}$ & 1781.898 & 1666.364 & $\underline{\mathbf{2 5 2 . 2 7 2}}$ \\
\hline $\mathrm{Pb}$ & 22370.229 & 1633.336 & 777.429 & 108.957 \\
\hline $\mathrm{Al}$ & 1798887.612 & $\underline{\mathbf{1 3 0 4 3 9 6 . 2 4 8}}$ & 944049.848 & $\underline{\mathbf{1 2 5 8 3 3 5 . 8 4 3}}$ \\
\hline $\mathrm{Zn}$ & 101458.916 & 69557.614 & 41156.918 & 32604.789 \\
\hline $\mathrm{Mg}$ & 41628.887 & 178232.106 & 67933.710 & 275107.263
\end{tabular}

Iron was found to be at the highest level in all of the fungi samples from the Demiralan locality (Table 8). The lowest level of lead was seen in M1, of cadmium in M2, and of cobalt in M3. The highest amount of $\mathrm{Fe}$ in the soil samples was observed in the Demiralan locality followed by $\mathrm{Al}, \mathrm{Zn}, \mathrm{Mg}$,
$\mathrm{Cr}$, and $\mathrm{Ni}$. The fungi samples contained more $\mathrm{Mg}$ than the soil. Depending on the amount of soil, the fungi samples still contained more $\mathrm{Zn}$ (Table 8). The distribution of minerals in soil samples is given in Table 9.

Table 8 . Heavy metal contents in fungi samples detected at the Demiralan locality (ppm)

\begin{tabular}{lllll}
\hline & T7 & M1- & M2- & M3- \\
& Demiralan & C. rutilus & S. grevillei & H. sinapizans \\
\hline $\mathrm{Cr}$ & 43840.567 & 1302.144 & 3293.871 & 3583.244 \\
\hline $\mathrm{Fe}$ & $\underline{\mathbf{2 8 0 4 0 0 5 5 . 7 3}}$ & 434882.741 & 1523078.247 & $\underline{\mathbf{1 1 0 1 5 2 3 . 5 1 9}}$ \\
\hline $\mathrm{Co}$ & 13652.114 & 339.097 & 739.927 & $\underline{\mathbf{5 7 4 . 8 0 4}}$ \\
\hline $\mathrm{Ni}$ & 43701.854 & 1072.255 & 3036.071 & 2599.885 \\
\hline $\mathrm{Cu}$ & 30797.234 & 5125.301 & 5814.112 & 22236.064 \\
\hline $\mathrm{Cd}$ & $\mathbf{\mathbf { 8 5 8 . 3 5 9 }}$ & 294.250 & $\underline{\mathbf{2 2 0 . 6 0 4}}$ & 2740.581 \\
\hline $\mathrm{Pb}$ & 24641.466 & $\mathbf{7 7 . 4 0 9}$ & $\mathbf{1 2 4 2 . 6 5 4}$ & 1604.243 \\
\hline $\mathrm{Al}$ & 3688657.174 & $\underline{\mathbf{7 9 5 7 9 8 . 1 4 5}}$ & $\underline{\mathbf{1 0 5 5 0 2 0 . 8 9 1}}$ & 994395.611 \\
\hline $\mathrm{Zn}$ & 102068.52 & 17954.607 & 41183.402 & 107683.340 \\
\hline $\mathrm{Mg}$ & 64872.337 & 111306.657 & 18140.375 & 272228.957 \\
\hline
\end{tabular}


Table 9. Heavy metal contents detected in soil samples (ppm)

\begin{tabular}{lllllllll}
\hline & $\begin{array}{c}\text { Madenli } \\
\mathrm{T} 1\end{array}$ & $\begin{array}{c}\text { Madenli } 2 \\
\mathrm{~T} 2\end{array}$ & $\begin{array}{c}\text { Kuğulu Park } \\
\mathrm{T} 3\end{array}$ & $\begin{array}{c}\text { Upper site of } \\
\text { Toki } \\
\mathrm{T} 4\end{array}$ & $\begin{array}{c}\text { Pond } \\
\mathrm{T} 5\end{array}$ & $\begin{array}{c}\text { The Taraşç1 } \\
\text { Pond } \\
\text { T6 }\end{array}$ & $\begin{array}{c}\text { Demiralan } \\
\mathrm{T} 7\end{array}$ & $\begin{array}{c}\text { Fabrika } \\
\text { T8 }\end{array}$ \\
\hline $\mathrm{Cr}$ & 83217.722 & 129426.436 & 29072.504 & 28146.368 & 31178.19 & 28651.941 & 43840.567 & 28877.512 \\
\hline $\mathrm{Fe}$ & $\mathbf{3 7 1 8 4 0 3 0 . 2 4}$ & $\mathbf{2 7 4 7 3 2 1 3 . 6 3}$ & $\mathbf{2 5 6 7 0 2 2 6 . 9 4}$ & $\mathbf{2 4 1 1 7 3 4 7 . 6 9}$ & $\mathbf{1 9 5 8 2 4 1 1 . 3 1}$ & $\mathbf{2 5 4 5 7 4 5 5 . 3 1}$ & $\mathbf{2 8 0 4 0 0 5 5 . 7 3}$ & $\mathbf{2 7 9 7 8 6 0 4 . 7 5}$ \\
\hline $\mathrm{Co}$ & 25956.669 & 26178.954 & 11907.879 & 11556.847 & 11289.413 & 13871.601 & 13652.114 & 12039.85 \\
\hline $\mathrm{Ni}$ & 82598.173 & 329905.67 & 42666.119 & 42204.671 & 26954.817 & 22880.592 & 43701.854 & 30541.133 \\
\hline $\mathrm{Cu}$ & 33654.812 & 32231.589 & 24027.744 & 42365.505 & 27638.305 & 75106.306 & 30797.234 & 21964.456 \\
\hline $\mathrm{Cd}$ & 4522.193 & 137.803 & 1045.973 & 1412.006 & 402.692 & 96.705 & 858.359 & 180.729 \\
\hline $\mathrm{Pb}$ & 34830.167 & 9149.192 & 16032.553 & 17580.387 & 16343.625 & 22370.229 & 24641.466 & 16463.377 \\
\hline $\mathrm{Al}$ & $\mathbf{2 7 5 0 1 8 5 . 2 3 2}$ & $\mathbf{1 0 1 6 5 8 3 8 . 9 9}$ & $\mathbf{1 9 9 0 8 8 0 . 3 4 6}$ & $\mathbf{1 4 8 4 8 6 8 . 4 1 3}$ & $\mathbf{1 8 8 0 3 8 5 . 5 8 3}$ & $\mathbf{1 7 9 8 8 8 7 . 6 1 2}$ & $\mathbf{3 6 8 8 6 5 7 . 1 7 4}$ & $\mathbf{2 5 3 0 4 9 6 . 0 6 7}$ \\
\hline $\mathrm{Zn}$ & 127915.439 & $\mathbf{6 9 9 3 8 . 8 3 7}$ & 92884.818 & 88091.452 & 62798.279 & 101458.916 & 102068.52 & 63966.81 \\
\hline $\mathrm{Mg}$ & 99090.018 & 127395.762 & 126033.101 & 60607.686 & 42022.419 & 41628.887 & 64872.337 & $\mathbf{7 8 2 9 2 . 5 0 2}$ \\
\hline
\end{tabular}

The soil samples were compared with the samples taken from the factory localities. When the soil samples were examined, there was not much difference between the mineral quantities in the factory locality coded as T8, and the mineral amounts in the samples taken from other regions. Only Maden and Maden 2 localities were found to be rich in $\mathrm{Fe}$ and Al.

When the fungi were examined in terms of absorbing the percentage of heavy metals in the soil, the results were interesting. In the fungi detected in locality 1 , especially in the fungi taken from the $\mathrm{Cu}$ and $\mathrm{Zn}$ localities, the heavy metals content was over $50 \%$. Again, the $\mathrm{Cd}$ and $\mathrm{Mg}$ in two fungi and the $\mathrm{Al}$ in one fungus increased to over $50 \%$ in terms of content (Table 10).

When the heavy metal content in the fungi detected in locality 2 was examined, it was over $50 \%$, especially in all fungi taken from $\mathrm{Zn}$ localities. Again, the $\mathrm{Cu}$ and $\mathrm{Cd}$ levels were higher than $50 \%$ in two fungi and $\mathrm{Mg}$ was higher than $50 \%$ in one fungus (Table 10).

Table 10. Percentage of heavy metals in terms of the soil in fungi at the Maden and Maden 2 localities

\begin{tabular}{lllllll}
\hline & L1-M1 & L1-M2 & L1-M3 & L2-M1 & L2-M2 & L2-M3 \\
\hline $\mathrm{Cr}$ & 12.70996 & 2.383413 & 7.259827 & 6.343882 & 0.804391 & 2.247324 \\
\hline $\mathrm{Fe}$ & 2.565957 & 1.330714 & 5.399336 & 3.153039 & 0.630205 & 0.852143 \\
\hline $\mathrm{Co}$ & 2.853926 & 1.485137 & 4.913647 & 9.016957 & 1.934672 & 1.702539 \\
\hline $\mathrm{Ni}$ & 3.337178 & 1.509715 & 5.828453 & 5.771567 & 0.23075 & 1.076033 \\
\hline $\mathrm{Cu}$ & 462.7939 & 217.1894 & 212.2763 & 195.387 & 23.84659 & 181.9639 \\
\hline $\mathrm{Cd}$ & 358.5806 & 24.23141 & 266.8097 & 2848.059 & 28.07704 & 630.8934 \\
\hline $\mathrm{Pb}$ & 1.084827 & 1.964673 & 12.24921 & 435.5571 & none & none \\
\hline $\mathrm{Al}$ & 42.60314 & 54.58931 & 41.96046 & 17.91017 & 8.144704 & 18.09943 \\
\hline $\mathrm{Zn}$ & 89.99194 & 90.65265 & 111.755 & 188.0306 & 57.1866 & 126.3005 \\
\hline $\mathrm{Mg}$ & 77.95926 & 23.03905 & 99.87699 & 61.43492 & 15.55908 & 40.16792 \\
\hline
\end{tabular}

When the heavy metal content of the fungi detected in locality 3 were examined, it was seen that there was over $50 \%$ content in all mushrooms taken from $\mathrm{Cu}, \mathrm{Cd}$, and $\mathrm{Zn}$ localities. $\mathrm{Al}$ and $\mathrm{Mg}$ were at more than a $50 \%$ level in two fungal species (Table 11).

When the heavy metal contents of the fungi detected in the locality 4 were examined, especially in all mushrooms taken from the $\mathrm{Zn}$ localities, heavy metals were present at a level of over $50 \%$. Cu, Cd, Al, and $\mathrm{Mg}$ levels were higher than $50 \%$ in two fungal species (Table 11). 
Table 11. Percentage of heavy metals in fungi found in soil at the Kugulu Park (L3) and Toki (L4) localities

\begin{tabular}{llllllll}
\hline & L3-M1 & L3-M2 & L3-M3 & L3-M4 & L4-M1 & L4-M2 & L4-M3 \\
\hline $\mathrm{Cr}$ & 6.758321 & 1.747335 & 2.698416 & 3.031025 & 5.231222 & 10.50903 & 31.65686 \\
\hline $\mathrm{Fe}$ & 3.964942 & 0.429712 & 0.668584 & 0.434886 & 3.772548 & 5.660965 & 23.37572 \\
\hline $\mathrm{Co}$ & 6.386276 & 19.13719 & 3.151871 & 1.683264 & 4.243761 & 5.4259 & 24.93601 \\
\hline $\mathrm{Ni}$ & 5.082279 & 2.749437 & 2.460693 & 1.776445 & 3.508958 & 6.351567 & 24.63662 \\
\hline $\mathrm{Cu}$ & 298.3362 & 142.5864 & 93.0502 & 265.3747 & 31.70688 & 111.692 & 277.4885 \\
\hline $\mathrm{Cd}$ & 84.37713 & 312.6796 & 485.3633 & 100.1742 & 10.75867 & 918.0211 & 51.96111 \\
\hline $\mathrm{Pb}$ & 2.791789 & none & none & 2.342765 & 1.920674 & 4.752432 & 73.52243 \\
\hline $\mathrm{Al}$ & 88.90193 & 40.21762 & 45.14622 & 79.63397 & 41.95338 & 70.97244 & 92.32203 \\
\hline $\mathrm{Zn}$ & 152.2185 & 85.85241 & 59.90935 & 146.8256 & 42.10743 & 59.26845 & 151.8859 \\
\hline $\mathrm{Mg}$ & 72.40387 & 47.42799 & 71.01442 & 26.39437 & 1397.897 & 22.2127 & 540.1121 \\
\hline
\end{tabular}

When the heavy metal contents in the fungi detected in locality 5 were examined, especially the fungi from the $\mathrm{Cu}, \mathrm{Cd}$ and $\mathrm{Zn}$ localities, they contained heavy metal levels of more than $50 \%$. $\mathrm{Al}$ and $\mathrm{Mg}$ was found at a higher than $50 \%$ level in three of the fungus types (Table 12).
When the heavy metal contents in the fungi detected in locality 6 were examined, it was seen that there are heavy metals at an over $50 \%$ content level in all fungi taken from the $\mathrm{Cd}, \mathrm{Al}$, and $\mathrm{Mg}$ localities. Again, $\mathrm{Zn}$ increased to over $50 \%$ in one of the fungus species (Table 12).

Table 12. Percentage of heavy metals in fungi in Pond (L5) and the Taraşçı Reservoir (L6) localities

\begin{tabular}{lllllllll}
\hline & L5-M1 & L5-M2 & L5-M3 & L5-M4 & L5-M5 & L6-M1 & L6-M2 & L6-M3 \\
\hline $\mathrm{Cr}$ & 9.152215 & 7.050085 & 1.560604 & 18.57716 & 33.35344 & 11.16109 & 7.242937 & 8.993865 \\
\hline $\mathrm{Fe}$ & 2.328589 & 1.789424 & 0.592219 & 5.195746 & 9.446993 & 4.709341 & 4.086928 & 3.609414 \\
\hline $\mathrm{Co}$ & 3.284077 & 2.452368 & 1.235396 & 5.900776 & 9.179388 & 10.31332 & 4.344466 & 3.574807 \\
\hline $\mathrm{Ni}$ & 7.578145 & 3.521122 & 1.384064 & 8.923563 & 13.08729 & 13.64008 & 13.84291 & 12.52699 \\
\hline $\mathrm{Cu}$ & 63.36974 & 92.62255 & 67.43674 & 203.7737 & 89.29585 & 60.9529 & 18.45454 & 14.65758 \\
\hline $\mathrm{Cd}$ & 332.4891 & 135.0126 & 946.133 & 451.7351 & 96.97834 & 1842.612 & 1723.142 & 260.8676 \\
\hline $\mathrm{Pb}$ & 0.846428 & none & none & 12.04854 & 6.968515 & 7.301383 & 3.475284 & 0.487063 \\
\hline $\mathrm{Al}$ & 42.34422 & 32.38423 & 61.14758 & 57.69781 & 54.24086 & 72.51127 & 52.47965 & 69.95078 \\
\hline $\mathrm{Zn}$ & 122.3565 & 93.08098 & 53.35938 & 208.2908 & 86.77844 & 68.55742 & 40.56511 & 32.13595 \\
\hline $\mathrm{Mg}$ & 36.78977 & 54.02138 & 249.2029 & 90.13843 & 28.30523 & 428.1453 & 163.1889 & 660.8566 \\
\hline
\end{tabular}

When the heavy metal contents in the fungi detected in locality 7 was examined, there was a content of more than $50 \%$ in the fungus type taken from the localities of $\mathrm{Cu}$,
$\mathrm{Cd}$, and $\mathrm{Zn}$. Again, the $\mathrm{Mg}$ level increased more than $50 \%$ in two of the fungi species (Table 13).

Table 13. Percentage of heavy metals in fungi located in the Demiralan locality

\begin{tabular}{llll}
\hline & L7-M1 & L7-M2 & L7-M3 \\
\hline $\mathrm{Cr}$ & 2.970181 & 7.513295 & 8.173352 \\
\hline $\mathrm{Fe}$ & 1.550934 & 5.431795 & 3.928393 \\
\hline $\mathrm{Co}$ & 2.483842 & 5.419871 & 4.210366 \\
\hline $\mathrm{Ni}$ & 2.453569 & 6.947236 & 5.949141 \\
\hline $\mathrm{Cu}$ & 16.64208 & 18.87868 & 72.2015 \\
\hline $\mathrm{Cd}$ & 34.28053 & 25.70067 & 319.2814 \\
\hline $\mathrm{Pb}$ & 0.314141 & 5.042939 & 6.510339 \\
\hline $\mathrm{Al}$ & 21.5742 & 28.60176 & 26.9582 \\
\hline $\mathrm{Zn}$ & 17.59074 & 40.34878 & 105.501 \\
\hline $\mathrm{Mg}$ & 171.578 & 27.96319 & 419.638 \\
\hline
\end{tabular}


The lowest and highest heavy metals specified in the fungi may be seen in Table 14; the fungi containing the most heavy metals were found in the Madenli, Madenli
2, and Upper site of Toki localities while the fungi containing the lowest levels of heavy metals in were in the Pond and Demiralan localities.

Table 14. Heavy metals detected in fungi at the highest and lowest amounts

\begin{tabular}{lll}
\hline & En fazla & En az \\
\hline $\mathrm{Cr}$ & L1-M1 & L5-M5 \\
\hline $\mathrm{Fe}$ & L4-M3 & L3-M2 \\
\hline $\mathrm{Co}$ & L4-M3 & L5-M3 \\
\hline $\mathrm{Ni}$ & L2-M1 & L5-M3 \\
\hline $\mathrm{Cu}$ & L1-M1 & L7-M1 \\
\hline $\mathrm{Cd}$ & L1-M1 & L2-M2 \\
\hline $\mathrm{Pb}$ & L2-M1 & (L2-M2,M3/L3-M2,M3/L5-M2,M3=0)L7-M1 \\
\hline $\mathrm{Al}$ & L2-M3 & L5-M2 \\
\hline $\mathrm{Zn}$ & L1-M3 & L7-M1 \\
\hline $\mathrm{Mg}$ & L2-M1 & L5-M5 \\
\hline
\end{tabular}

In terms of the sum of all heavy metals, the amount contained in the fungi is given in Figure 2.

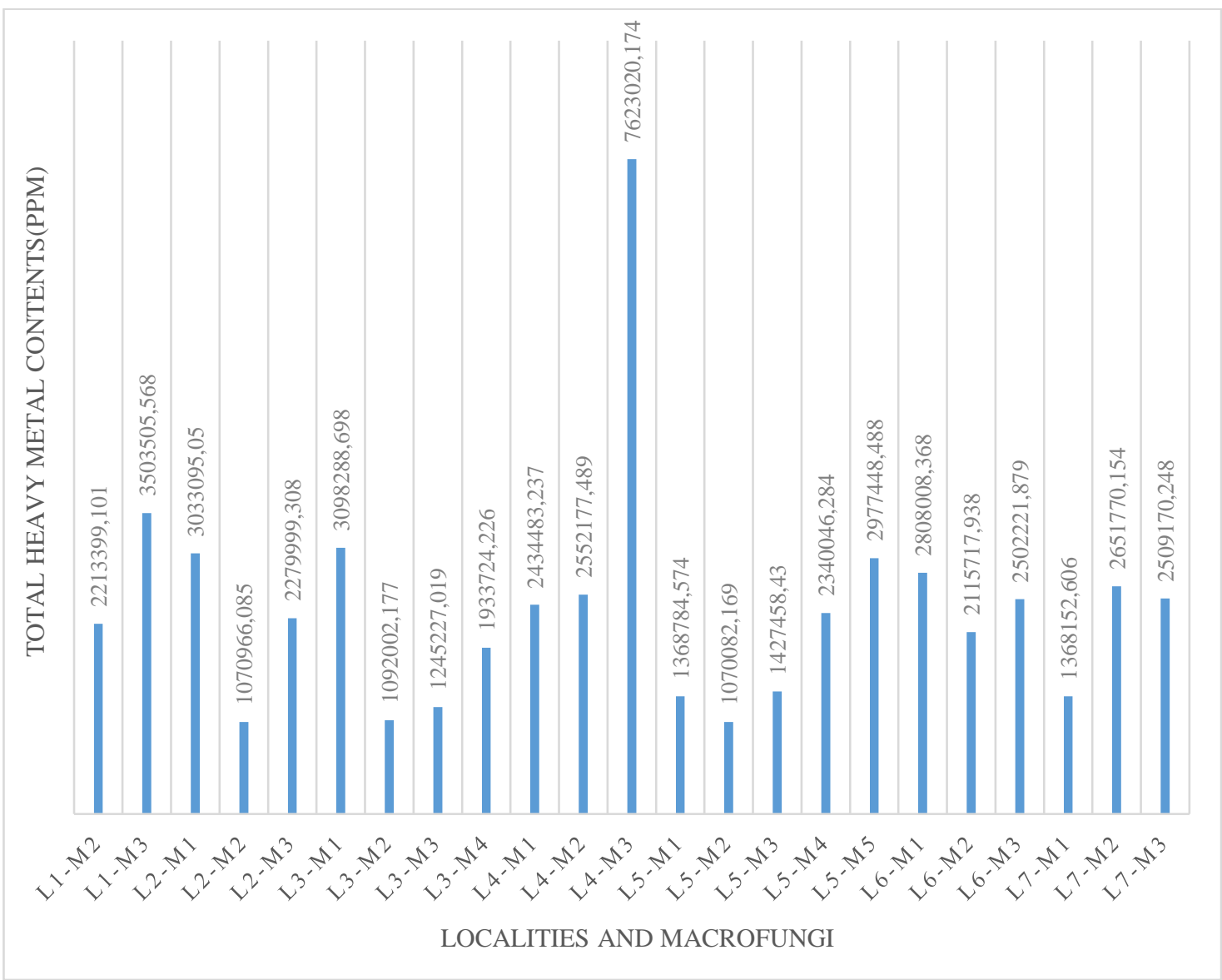

Figure 2. Total amount of heavy metals contained in fungi (ppm)

Figure 2 shows that while all the fungi contain similar proportions of heavy metal, in the L4-M3, the heavy metal content was observed to be denser by comparison. The lowest level of heavy metal content was found in the L5-M2, L2-M2, and L3-M2 samples.

The total heavy metal contents of the soil 
samples are given in Figure 3 where it may be seen that the highest level of heavy metal content was found in the Madenli and
Madenli 2 localities while the lowest level of heavy metal content was detected in the Pond locality.

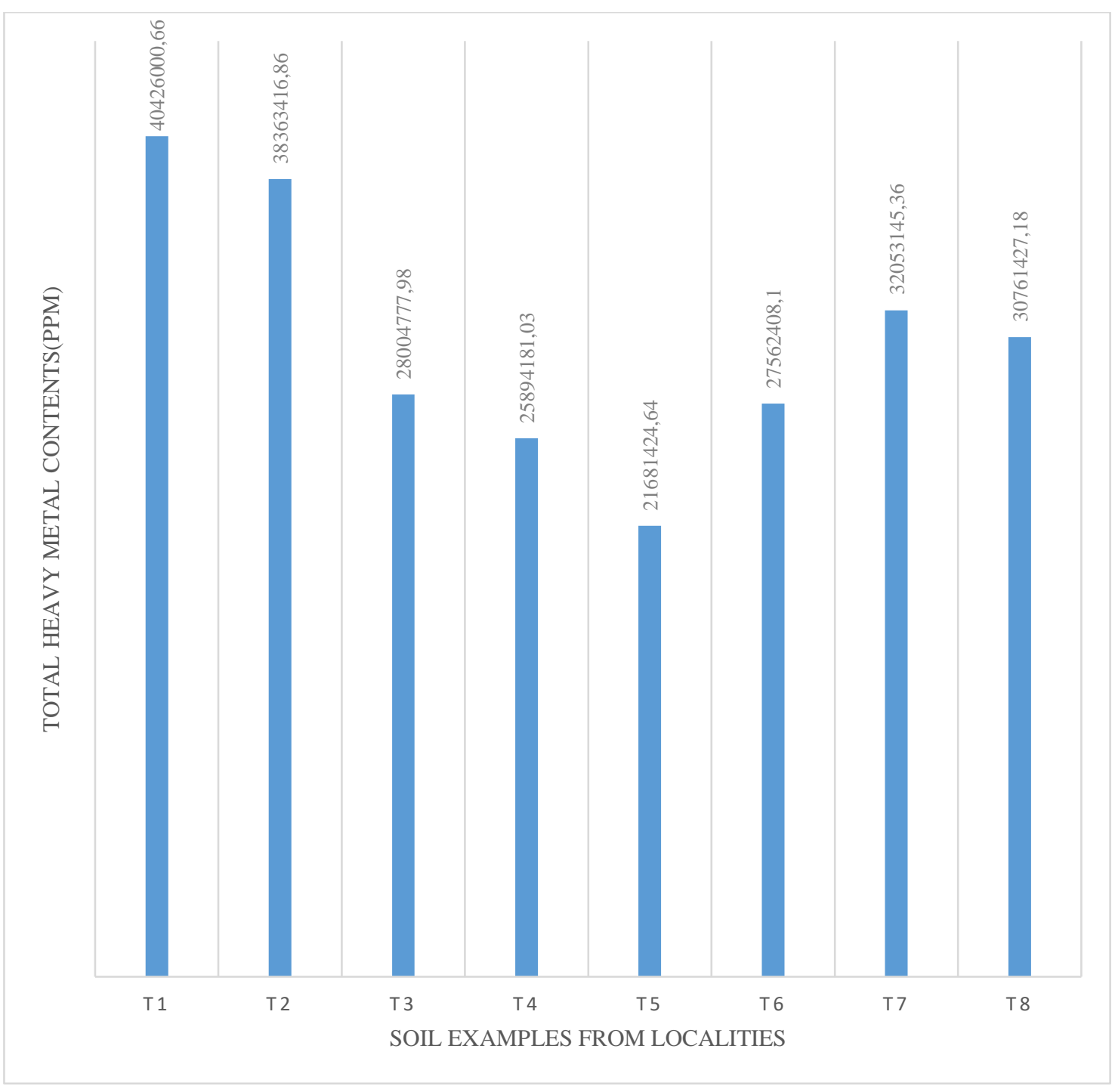

Figure 3. Total amount of heavy metal in soil samples taken from localities (ppm)

\section{Discussion}

This study examined the heavy metal quantities in the macrofungi growing in the Seydişehir (KONYA) district. In the study, the forest areas around the Seydişehir district were investigated. Two of the localities were chosen from the regions far from the city center, and the others were located in the city center where a point close to the factory was chosen. As a result of the field studies carried out in all localities, samples were taken from macrofungi that could be used in heavy metal accumulation. Soil samples were taken from the same localities and brought to the laboratory.

When the results of the analysis were evaluated, the presence of heavy metals was detected, and an analysis of 10 different heavy metals was conducted in soil samples taken from the research area. Although the amount of heavy metals varied among localities, it was determined that there was a strong presence of $\mathrm{Fe}$ and $\mathrm{Al}$ in the soil samples from Seydişehir. $\mathrm{Fe}$ ranged between $195822411 \mathrm{ppm}$ and $37184030 \mathrm{ppm}$ in localities. Al ranged between $1484868 \mathrm{ppm}$ and $3688657 \mathrm{pmm}$. 
In addition, the presence of $\mathrm{Zn}$ in almost all localities was determined, found at levels between $62798.279 \mathrm{ppm}$ and $127915.439 \mathrm{ppm}$. Similarly, in all localities, the level of $\mathrm{Mg}$, ranging between $41628.887 \mathrm{ppm}$ and $127395.762 \mathrm{ppm}$, was found to be higher than other minerals. In addition, the level of $\mathrm{Cu}$ was determined to range between $75106.306 \mathrm{ppm}$ and $21964.456 \mathrm{ppm}$.

When the heavy metal content of the fungi was considered, it was observed that the minerals with a high density in the locality have the same rate in the fungus structure. The amount of $\mathrm{Fe}$ and $\mathrm{Al}$ detected in the region was observed to be at a high level in the content of the fungi. In addition to $\mathrm{Al}$ and $\mathrm{Fe}, \mathrm{Cu}, \mathrm{Zn}, \mathrm{Cd}$, and $\mathrm{Mg}$ were found at higher levels than other minerals in the fungi samples.

Although some $\mathrm{Pb}$ was found in some fungi in the given localities, in some localities $\mathrm{Pb}$ could not be detected and identified. Depending on the density of heavy minerals in the environment, transition through the fungi bodies was also observed. However, percentages of some minerals from fungi to fungi differed based on other minerals. $\mathrm{Cu}, \mathrm{Cd}, \mathrm{Zn}, \mathrm{Al}$, and $\mathrm{Mg}$, in particular, were inclined to make transition more substantial in terms of percentage.

When the heavy metal contents of the mushrooms are expressed in percentage depending on the heavy metal content in the soil, $\mathrm{Fe}$ and $\mathrm{Al}$ are very high in the soils. Although in the mushroom's tissue structure are also high, it seems low, when viewed in terms of the percentage of heavy metal in the soil.

When the soil samples were compared, there was no significant difference between soil samples taken from the factory localities and the soil samples taken from other regions. $\mathrm{Fe}$ and $\mathrm{Al}$ were high in all localities. In addition, $\mathrm{Cr}, \mathrm{Ni}, \mathrm{Zn}$, and $\mathrm{Mg}$ were found in the localities of Kuğulu Park, Toki, and Pond; Demiralan showed a presence of $\mathrm{Zn}$ and $\mathrm{Mg}$; and, in the The Taraşçı Pond localities where levels of $\mathrm{Cu}$ and $\mathrm{Zn}$ were higher than other heavy metals.

Emissions from rapidly expanding industrial areas can be contaminated by the accumulation of heavy metals and metalloids through the land application of fertilizers, coal combustion residues and pouring of petrochemicals. The presence of metals in the fruiting bodies of mushrooms directly reflects their amount in the soil, and bioaccumulation factors indicate the ability of mushrooms to accumulate these elements from the soil (Lalotra et al., 2016). It is seen that the data obtained in this study is high. There may be several reasons for this. The first is naturally the abundance of mines in the working area, the second may be the result of industrialization and modernization, and the result of industrial elements operating in the region. And the above reasons can be added to these.

According to the literature review, Lepsova ve Mejstrik (1988) stated that the fungus grown in mineral deposits are high in $\mathrm{Pb}$ and Cd content. Kalac et al. (1991) stated that similar minerals $(\mathrm{Pb}, \mathrm{Cd})$ accumulate in cork mushrooms/fungi and that the $\mathrm{Pb}, \mathrm{Cd}$, $\mathrm{Cu}$ and $\mathrm{Hg}$ levels were significant in fungi growing near lead deposits.

Iş1ldak et al. (2004), in a study of the heavy metal contents of edible macrofungi growing naturally in the Tokat region, reported that the $\mathrm{Fe}$ content is high in all fungi whereas $\mathrm{Cr}$ and $\mathrm{Ni}$ are high in some species.

According to Durukan (2006) it was determined that the $\mathrm{Cu}$ and $\mathrm{Zn}$ content in the macrofungi was higher than the heavy metal content in the soil. This result was also verified and similar in our study.

The study by Şen et al. (2012) that examined the heavy metal content specified for the natural fungi grown in Bigadiç (Balıkesir) in terms of $\mathrm{Cd}, \mathrm{Cr}, \mathrm{Cu}$, and $\mathrm{Zn}$ showed similar results to our study. Some differences in the content should be evaluated in terms of habitat differences.

Altıntığ et al. (2017) conducted a study called detection of $\mathrm{Cr}, \mathrm{Cu}, \mathrm{Fe}, \mathrm{Ni}, \mathrm{Pb}$ and $\mathrm{Zn}$ with ICP-OES in mushroom samples collected from Sakarya. Considering the results of our study, the amount of $\mathrm{Fe}$ in the studied mushrooms, Altıntığ et al. (2017) when compared with his work, it is seen that it has come out too much. There are differences in other elements. This can be interpreted by the difference of the growing place of the mushroom. 
Although the mineral content of the macrofungi was in line with mineral richness up to a certain level, it is not possible to talk about this linearity in terms of an excess amount of minerals in the environment. Mineral absorption is thought to be related to the structure of the fructification organ of the fungus. Macrofungi have been found to have the ability to strongly absorb minerals in the environment. Compared with green plants, macrofungi can accumulate high concentrations of heavy metals such as $\mathrm{Cd}$, $\mathrm{Pb}$ and $\mathrm{Hg}$ (An \& Zhou, 2007). Attention should be paid to the consumption of macrofungi grown in soils rich in heavy metals. Excessive consumption can pose a threat to human health.

\section{Acknowledgments}

Funding: This research was supported by Selçuk University Scientific Research Projects (BAP) Coordination Office (Project No: 15401109). Thank you for their financial support.

Conflict of interest: The authors declare that they have no conflict of interest.

\section{References}

Akgül, H., Sevindik, M., Akata, I., Altuntaş, D., Bal, C. \& Doğan, M. (2016). Macrolepiota procera (Scop.) Singer. Mantarının Ağır Metal İçeriklerinin ve Oksidatif Stres Durumunun Belirlenmesi Süleyman Demirel Üniversitesi Fen Bilimleri Enstitüsü Dergisi. 20(3), 504508.

Akın, İ., Alkan, S. \& Kaşık, G. (2019). Determination of Heavy Metal Accumulation in Some Mushrooms of Agaricaceae Family Collected from Çorum Province. The Journal of Fungus 10(1), 48-55.

Altıntı̆̆, E., Hişir, M. E., \& Altundağ, H. (2017). Determination of $\mathrm{Cr}, \mathrm{Cu}, \mathrm{Fe}, \mathrm{Ni}, \mathrm{Pb}$ and $\mathrm{Zn}$ by ICP-OES in mushroom samples from Sakarya, Turkey. Sakarya University Journal of Science, 21(3), 496-504.

Al-Garni S. M. (2005) Biosorption of lead by Gram-ve capsulated and non-capsulated bacteria. Water SA,. 31,345-50.

Amini, M., Younesi, H., Bahramifar, N., Akbar, A., Lorestani, Z., Ghorbani, F., Daneshi, A. \& Sharifzadeh, M. (2008). Application of response surface methodology for optimization of lead biosorption in an aqueous solution by Aspergillus niger. Hazardous Materials 154, 694.
An, X. L. \& Zhou, Q. 0X. (2007). Bioaccumulation of heavy metals in macrofungi and its application in ecological remediation. Pubmed, NCBI, 18(8):18971902.

Assche, F. \& Clijsters, H. (1990) Effects of metals on enzyme activity in plants. Plant, Cell and Environment, 24, 1-15.

Breitenbach, J., \& Kranzlin, F. (1986). Fungi of Switzerland (Vol. Volume 2. Nongilled Fungi). CH-6000 Luzern 9, Switzerland: Verlag Mykologia.

Breitenbach, J., \& Kranzlin, F. (1991). Fungi of Switzerland (Vol. Volume 3. Boletes and Agarics 1. Part). CH-6000 Luzern 9, Switzerland: Verlag Mykologia.

Breitenbach, J., \& Kranzlin, F. (1995). Fungi of Switzerland (Vol. Volume 4.). CH-6000 Luzern 9, Switzerland: Verlag Mykologia.

Breitenbach, J., \& Kranzlin, F. (2005). Fungi of Switzerland (Vol. Volume 5.). CH-6000 Luzern 9, Switzerland.: Verlag Mykologia.

Campbell, N.A. \& Reece, J.B., (2008). Biyoloji, Altıncı Baskıdan Çeviri, Gündüz, E., Demirsoy, A. ve Türkan, İ. (Çeviri Editörleri), Palme Yayıncilık.

Canet, L., Ilpide, M. \& Seat, P. (2002). Efficient facilitated transport of lead, cadmium, zinc and silver across a flat sheet-supported liquid membrane mediaed by lasalocid A. Sep. Sci. Technol., 37, 1851-1860.

Cibulka, J., Sisak, L., Pulkrab, K., Szakova, J., \& Fucikova, A. (1996). Cadmium, lead, mercury, and caesium levels in wild mushrooms and forest berries from different localities of the Czech Republic. Scintia Agriculturae Bohemica, 27, 113-129.

Dahncke, R. M. (1993). 1200 Pilze. Stuttgart: AT Verlag.

Demirbaş, A. (2000). Accumulation of heavy metals in some edible mushrooms from Turkey. Food Chemistry, 68, 415-419.

Demirbaş, A. (2001a). Concentrations of 21 metals in 18 species of mushrooms growing in the East Black sea region. Food Chemistry, 75, 453-457.

Demirbaş, A. (2001b). Heavy metal bioaccumulation by mushrooms from artificially fortified soil. Food Chemistry, 74, 293-301.

Demirbaş, A. (2001c). Levels of trace elements in the fruiting bodies of mushrooms growing in the East Black sea region. Energy Education Science \& Technology, 7(2), 67-81.

Demirbaş, A. (2002). Metal ion uptake by mushrooms from natural and artificially enriched soils. Food Chemistry, 78, 89-93.

Doğan, H. H., Şanda, M. A., Uyanöz, R., Öztürk, 
C. \& Çetin, Ü. (2006). Contents of Metals in Some Wild Mushrooms Its Impact in Human Health. Biological Trace Element Research, 110, 79-94.

Dulay, R.M.R., Cabalar, A.C., De Roxas, M.J.B., Concepcion, J.M.P., Cruz, N.E., Esmeralda, M., Jimenez, N., Aguilar, J.C., De Guzman, E.J., Santiago, J.Q., Samoy, J.R., Bustillos, R.G., Kalaw, S.P. \& Reyes, R.G. (2015). Proximate composition and antioxidant activity of Panaeolus antillarium, a wild coprophilous mushroom. Current Research in Environmental and Applied Mycology 5(1), 52-59.

Durukan, N. (2006). Yukarl Büyük Menderes Nehri havzasındaki Makrofungus $\neg$ larda Ăglr Metal İçeriklerinin Araştırılması. Doktora Tezi. Süleyman Demirel Üniv., Isparta.

Elekes, C. C., Busuioc, G. \& Ionita, G. (2010). The bioaccumulation of some heavy metals in the fruiting body of wild growing mushrooms. Notulae Botanicae Horti Agrobotanici ClujNapoca 38, 147-151.

Ellis, M. B., \& Ellis, J. P. (1990). Fungi Without Gills (Hymenomycetes and Gasteromycetes). London: Chapman and Hil.

Esalah, O. J., Weber, M. E. \& Vera, J.H. (2000). Removal of lead, cadmium and zinc from aqueous solutions by precipitation with sodium di-(n-octyl) phosphinate. Can. J. Chem. Eng., 78, 948-954.

Frankowska, A., Ziolkowska, J., Bielawski, L. \& Falandyz, J. (2010). Profile and bioconcentration of minerals by King bolete (Boletus edulis) from the Plocka Dale in Poland. Food Additives and Contamination 3(1), 1-6.

Gençcelep, H., Uzun, Y., Tunçtürk, Y. \& Demirel, K. (2009). Determination of mineral contents of wildgrown edible mushrooms. Food Chemistry 113: 1033-1036.

Grünert, H., \& Grünert, R. (1984). Pilze. München: Mosaik Verlag,Gmbh.

Grünert, H., \& Grünert, R. (1991). Field Guide to Mushrooms of Britain and Europe: The Crowood Press Ltd.

Gürsoy, N., Sarikürcü, C., Cengiz, M. \& Solak, M. (2009). Antioxidant activities, metal contents, total phenolics and flavonoids of seven Morchella species. Food Chemistry and Toxicology 47 (9), 2381-2388.

Ho, Y. S., Ng, J. C. Y. \& McKay, G. (2001). Removal of lead (II) from effluents by sorption on peat using second-order kinetics. Sep. Sci. Technol., 36, 241-261.

Ihab, A.altameemi, Thuraya, M.A., Tarikak, N. (2013). Anew simple method for the treatment of waste water containing $\mathrm{Cu}$ (II) and $\mathrm{Zn}$ (II)
Ions using adsorption on dried Conocarpus erectus leaves. Journal of Basrah Researches ((Sciences)), 39( 2), 125-136.

Işıldak, Ö., Türkekul, İ., Elmastaş, M., \& Tüzen, M. (2004). Analysis of Heavy Metals in Some Wild-Grown Edible Mushrooms from the Middle Black Sea Region, Turkey. Food Chemistry, 86, 547-552.

Jorhem, L., \& Sundström, B. (1995). Levels of some trace elements in edible fungi. Zeitschrift für Lebensmittel-Untersuchung und Forschung, 201, 311-316.

Kalač, P., Burda, J., \& Stašková, I. (1991). Concentrations of lead, cadmium, mercury and copper in mushrooms in the vicinity of a lead smelter. The Science of the Total Environment, 105, 109-119.

Kalač, P. \& Svoboda, L. (2000). A review of trace element concentrations in edible mushrooms. Food Chemistry 69, 273-281.

Kalač, P., Svoboda, B., \& Havlickova, H. (2004). Contents of detrimental metals mercury, cadmium and lead in wild growing edible mushrooms: a review. Energy Education Science and Technology, 13, 31-38.

Kalač, P., Wittingerova, M., Stašková, I., Simak, M., \& Bastl, J. (1989). Contents of mercury, lead, and cadmium in mushrooms. Ceskoslovenska Hygiena, 34, 568-576.

Karapınar, H. S., Uzun, Y. \& Kılıçel, F. (2017). Mineral Contents of Two Wild Morels. Anatolian Journal of Botany, 1(2), 32-36.

Kaşık, G. (2010). Mantar Bilimi. KONYA: Marifet Matbaa ve Kağıtçılık.

Kaya, A. \& Bağ, H. (2010). Trace element contents of edible macrofungi growing in Adiyaman, Turkey. Asian Journal of Chemistry, 22, 1515-1521.

Laaksovirta, K., \& Alakuijala, P. (1978). Lead, cadmium and zinc content on fungi in the parks of Helsinki. Annales Botanici Fennici, $15,253-257$

Lalotra, P., Gupta, D., Yangdol, R., Sharma, Y. P. \& Gupta S. K. (2016). Bioaccumulation of heavy metals in the sporocarps of some wild mushrooms. Current Research in Environmental \& Applied Mycology, 6(3), 159-165.

Lepšová, A., \& Kral, R. (1988). Lead and cadmium in fruiting bodies of macrofungi in the vicinity of a lead smelter. Science of the Total Environment, 76, 129-138.

Lepšová, A., \& Mejstŕík, V. (1988). Accumulation of trace elements in the fruiting bodies of macrofungi in the Krušné Hory Mountains, Czekhoslovakia. The Science of the Total Environment, 76, 117-128.

Magdziak, Z., Mleczek, M., Goliński, P., 
Siwulski, M.\& Szablewska. K. S. (2013). Concentration of minerals in selected edible mushroom species growing in Poland and their effect on human health. Acta Scientiarum Polonorum, Technologia Alimentaria, 12(2), 203-214.

Mazurkiewicz, N. \& Podlasinska, J. (2014). Bioaccumulation of trace elements in wildgrowing edible mushrooms from Lubuskie voivodeship, Poland. Chemistry and Ecology, 30(2), 110-117.

Michelot, D., Siobud, E., Dore, J. V., Viel, C., \& Poirier, F. (1998). Update of metal content profiles in mushrooms-toxicological implications and tentative approach to the mechanism of bioaccumulation. Toxicon, 36, 1997-2012.

Olumuyiwa, S. F., Oluwatoyin, O. A., Olanrewaja, O. \& Steve, R.A. (2007). Chemical composition and toxic trace element composition of some Nigerian edible wild mushroom. International Journal of Food Science and Technology, 43, 24-29.

Phillips, R. (1981). Mushrooms and Other Fungi of Great Britain and Europe. London.: Pan Books Ltd.

Proskura, N., J., P. n., \& Skopicz-Radkiewicz, L. (2017). Chemical composition and bioaccumulation ability of Boletus badius (Fr.) Fr. collected in western Poland. Chemosphere, 168, 106-111.

Radulescu, C., Stihi, C., Busuioc, G., Gheboianu, A.I. \& Popescu, I.V. (2010). Studies concerning heavy metals bioaccumulation of wild edible mushrooms from industrial area by using spectrometric techniques. Bulletin of Environmental Contamination and Toxicology 84, 641-646.

Raskin, I., Kumar, P. B. A. N., Dushenkov, S., \& Salt, D. E. (1994), Bioconcentration of heavy metals by plants. Current Opinion in Biotechnology, 5(3), 285-290.

Sarıkürkçü, C., Tepe, B., \& Solak, M. H. (2012). Metal Concentrations of Wild Edible Mushrooms from Turkey. Ecology of Food and Nutrition, 51, 346-363.

Sesli, E., \& Tüzen, M. (1999). Levels of trace elements in the fruiting bodies of macrofungi growing in the East Black Sea region of Turkey. Food Chemistry, 65, 453-460.

Smith, A., \& Smith, W. N. (1996). The Mushroom Hunter's Field Guide. Thunder Bay Press, Universty of Michigan: Michigan.

Svoboda, L., Zimmermannová, K., \& Kalač, P. (2000). Concentrations of mercury, cadmium, lead and copper in fruiting bodies of edible mushrooms in an emissions area of copper smelter and a mercury smelter. The Science of the Total Environment, 246, 61-76.

Şen, İ., Allı, H., Çöl, B., Çelikkollu, M., \& Balcı, A. (2012). Trace metal contents of some wildgrowing mushrooms Bigadiç (Balıkesir). Turk $J$ Bot, 36, 519-528.

Thomas, K. (1992). Heavy metals in urban fungi. Mycologist, 6, 195-196.

Türkekul, I., Elmastaş, M., \& Tüzen, M. (2004). Determination of iron, copper, manganese, zinc, lead, and cadmium in mushroom samples from Tokat, Turkey. Food Chemistry, 84, 389-392.

Tüzen, M. (2003). Determination of heavy metals in soil, mushroom and plant samples by atomic absorption spectrometry. Microchemical Journal, 74, 289-297.

Tüzen, M., Özdemir, M., \& Demirbaş, A. (1998). Study of heavy metals in some cultivated and uncultivated mushrooms of Turkish origin. Food Chemistry, 63, 247-251.

Uzun, Y., Gençcelep, H., Kaya, A. \& Akçay, M. E. (2011). The Mineral Contents of Some Wild Edible Mushrooms. Ekoloji, 20, 80, 612.

Vetter, J. (1987). Mineral elements in higher fungi. Mikológiai Közlemények, 26, 125-150.

Vetter, J. (1990). Mineral element content of edible and poisonous macrofungi. Acta Aliment., 19, 27-40.

Vetter, J. (1993). Toxic elements in certain higher fungi. Food Chemistry, 48, 207-208.

Vetter, J. (1994). Data arsenic and cadmium contents of some common mushrooms. Toxicon, 32(1), 11-15.

Wang, X. M., Zhang, J., Wub, L. H., Zhao, Y. L., Li, T., Li, J.Q., Wang, Y. Z., \& Liu, H. G. (2014). A mini-review of chemical composition and nutritional value of edible wild-grown mushroom from China. Food Chemistry, 151, 279-285.

Yamaç, M., Yıldız, D., Sarıürkçü, C., Çelikkollu, M. ve Solak, M. H. (2007). Heavy metals in some edible mushrooms from the Central Anatolia, Turkey. Food Chemistry, 103, 263-267.

Yılmaz, F., Işıloğlu, M., \& Merdivan, M. (2003). Heavy metals levels in some macrofungi. Turkish Journal of Botany, 27, 45-56. 